\title{
Autosomal recessive cutis laxa type 1
}

INSERM

\section{Source}

INSERM. (1999). Orphanet: an online rare disease and orphan drug data base. Autosomal recessive cutis laxa type 1. ORPHA:90349

Autosomal recessive cutis laxa, type 1 (ARCL1) is a generalized connective tissue disorder characterized by the association of wrinkled, redundant and sagging inelastic skin with severe systemic manifestations (lung atelectesias and emphysema, vascular anomalies, and gastrointestinal and genitourinary tract diverticuli). 